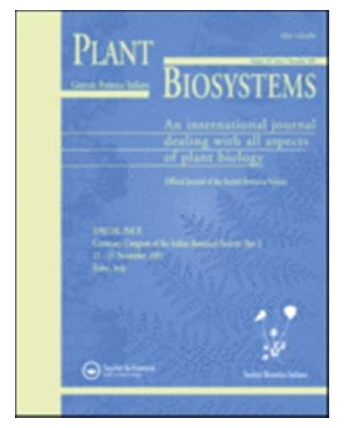

\title{
Comparative assessment of phytochemical profiles and antioxidant properties of Tunisian and Egyptian anise (Pimpinella anisum L.) seeds
}

\begin{tabular}{|r|l|}
\hline Journal: & Plant Biosystems \\
\hline Manuscript ID & TPLB-2017-0110.R2 \\
\hline Manuscript Type: & Original Article \\
\hline Date Submitted by the Author: & 20-Jul-2017 \\
\hline Complete List of Authors: & $\begin{array}{l}\text { Bettaieb Rebey, Iness; Laboratoire des Plantes Aromatiques et Médicinales, } \\
\text { Centre de Biotechnologie de Borj-Cédria, , ; } \\
\text { Bourgou, Soumaya; Centre de biotechnologie borj cedia } \\
\text { Aidi Wannes, Wissem; LSBA, } \\
\text { Hamrouni Sellami, Ibtissem ; Technoploe of Borj Cedria CBBC } \\
\text { Saidani Tounsi, Moufida; Laboratoire des Plantes Aromatiques et } \\
\text { Médicinales. Centre de Biotechnologie de Borj Cedria } \\
\text { Marzouk, Brahim; CBBC } \\
\text { Fauconnier, Marie-Laure; Universite de Liege Gembloux Agro-Bio Tech } \\
\text { Ksouri, Riadh; Laboratoire des Plantes Aromatiques et Médicinales. Centre } \\
\text { de Biotechnologie de Borj Cedria }\end{array}$ \\
\hline Keywords: & $\begin{array}{l}\text { Pimpinella anisum L., essential oil, fatty acids, phenolic, antioxidant } \\
\text { activity, provenance }\end{array}$ \\
\hline \hline
\end{tabular}


1 Comparative assessment of phytochemical profiles and antioxidant properties of Tunisian and Egyptian anise (Pimpinella anisum L.) seeds

3 I. BETTAIEB REBEY* ${ }^{1,2}$, S. BOURGOU ${ }^{1}$, W. AIDI WANNES ${ }^{1}$, I. HAMROUNI SELAMI ${ }^{1}$, 4 M. SAIDANI TOUNSI ${ }^{1}$, B. MARZOUK ${ }^{1}$, M. LAURE FAUCONNIER ${ }^{2}, \&$ R.KSOURI $^{1}$

${ }^{1}$ Laboratoire des Plantes Aromatiques et Médicinales, Centre de Biotechnologie de Borj-Cédria, BP 901, 2050 Hammem-Lif, Tunisie

7

8

${ }^{2}$ Laboratoire de Chimie Générale et Organique, Gembloux AgroBio Tech, Université de Liège, Passage des déportés, 2,5030

9

10 *Corresponding author:

Iness BETTAIEB REBEY (Tel: +21697547029; Fax: +21679412638);

12 E-mail: rosainess@yahoo.fr

13 (D) $\underline{0000-0001-8866-4685}$

14

15

16

17

18

19

20

21

22

23

24

25

26

27

28

29

59

60 


\begin{abstract}
30 Abstract
31 Anis (Pimpinella anisum L.) seeds obtained from two geographic origins Tunisia (TAS) and 32 Egypte (EAS) were studied regarding their biochemical composition and the antioxidant 33 potential of their extracts. The results showed that the highest value of oil was detected with 34 TAS compared to that of EAS ones. Ten (10) fatty acids were identified for the two locations 35 and petroselinic acid was the most prevalent in oil seeds and interestingly, TAS displayed a 36 significantly higher level of this acid than EAS. Besides, TAS exhibited slightly higher 37 essential oil yield than the Egyptian variety and that trans-anethole was the dominant for the two provenances. In both accessions, the highest total phenolic, flavonoid and tannin content was obtained with ethyl acetate fraction. Therefore, TAS exhibited higher chelating and 40 reducing powers than EAS which may be due to a slightly different phenolic composition 41 between the two accession seed extracts. The phenolic compositions of TAS and EAS 42 revealed that ethyl acetate extracts showed higher proportions of naringin, chlorogenic acid 43 and rosmarinic acid. However, ethanol extracts were richer in larcitrin, rosmarinic acid and 44 cirsimartin. The overall results revealed that aniseeds might constitute a novel source of 45 natural antioxidants and could be used as food additive.

$46 \quad$ Keywords
\end{abstract}

47 Pimpinella anisum L.; essential oil; fatty acids; phenolic; antioxidant activity; provenance. 
49

50

51

52

53

54

55

56

57

58

59

60

61

62

63

64

\section{Introduction}

The World Health Organization estimates that about $80 \%$ of the developing countries inhabitants rely on the traditional medicine for their primary health care needs, and that most of these therapies involve the use of plant extracts or their active components (WHO, 2000). Not only in developing countries but all over the world the use of medicinal plants has been playing a significant role in maintaining human health and improving the quality of human life. Thus, Fruits have become important for human nutrition due to their nutrients and potential beneficial health effects (Albuquerque et al. 2016).

Pimpinella anisum L. (P. anisum) has been widely used as a culinary ingredient as well as traditional remedies for the treatment of different disorders in the folk medicine systems of different civilizations. Aniseed contains $1.5-6.0$ mass $\%$ of a volatile oil consisting primarily of trans-anethole and also as much as $8-11$ mass $\%$ of lipids rich in fatty acids, such as palmitic and oleic acids, as well as approximately 4 mass $\%$ of carbohydrates, and 18 mass \% of protein (Besharati-seidani et al. 2005). Anise essential oil is mainly constituted by anethole, an aromatic substance that appears as the major compound of the oil, usually corresponding to more than $80 \%(w / w)$ of the oil (Samojlik et al. 2012; Özel 2009; Ullah and Honermeier 2013). Thus, seeds of anise are commonly recommended as antioxidant, antiseptic, antimicrobial, aperitif, digestive, antispasmodic (in respiratory and gastrointestinal tracts), expectorant, galactogogue, estrogenic, anti-inflammatory and diuretic agents, being these benefits mainly associated with the essential oil (Boskabady and Ramazani-Assari 2001; Shojaii and Fard 2012). Moreover, the oleochemical industry is increasingly interested in custom-made and novel oils with specific fatty acid compositions for applications in the oil and pharmaceutical industries (Murphy 1999). Such oils can be used for the synthesis of highquality products without expensive purification of raw materials. For the assessment of the 
73 nutritional and economical value of oilseeds the knowledge on the compositional factors is

74 very essential in connection with the properties (Ramadan and Wahdan 2012).

75 Moreover, application of synthetic antioxidants in food processing has led to the appearance 76 of remarkable side effects (Ebrahimabadi et al., 2010). Due to these limitations, there is an

77 increasing interest in finding naturally and biologically produced antioxidants capable of 78 inhibiting free radical reactions, retarding oxidative rancidity of lipids, protecting the human 79 body from diseases, and preserving foods from spoiling (Terao and Piskula 1997). What's 80 more, the antioxidant potential of plants was generally determined by the phenolic 81 compounds, being promoters of wellbeing and life expectancy of individuals (Li et al., 2014).

82 A few reports describe the phenolic profile of aniseeds (Marques and Farah 2009; Martins et 83 al. 2016). Thus, the composition of phenolic fractions present in P. anisum seeds is still 84 incompletely studied and some data are contradictory. Hence, in this study, we evaluated for 85 the first time the biochemical properties and the antioxidant potential of Tunisian aniseed 86 fractions and try to compare them with the Egyptian ones. Further, characterization of active 87 principle is needed to understand the effect of geographic origin on the chemical composition 88 of $P$. anisum seeds and so to improve their economic and health utilization as a source of 89 natural bioactive compounds.

\section{Materials and methods}

\section{$91 \quad$ Plant material and growth conditions}

92 Two accessions of mature aniseeds (Pimpinella anisum L.) were used in this work. The first 93 called (TAS) were harvested in June 2015 from the region of Korba in the northeast of 94 Tunisia; latitude $3634038.22^{\prime \prime}(\mathrm{N})$; longitude 1051029.63 ''(E) and the altitude is $637 \mathrm{~m}$. The 95 precipitation average was $400-500 \mathrm{~mm} /$ year and the monthly average temperature was $17.7 \mathrm{C}$. 96 The other seeds were reported to be imported from Egypt (EAS). 
97 Plant identification was carried by Professor Abderrzek Smaoui (Biotechnology Center in

98 Borj-Cedria Technopole, Tunisia). A voucher specimen was deposited at the herbarium of the 99 Laboratory of Bioactive Substances, Biotechnology Center in Borj-Cedria Technopole under 100 the "BC2011-2002" number. The two provenances were cultivated under the same 101 environmental conditions. Thus, seeds were transplanted to 101 pots filled with agricultural 102 soil which had a clayey-loamy texture and were irrigated with tap water. Experiments were 103 carried out in a greenhouse with a $14 \mathrm{~h}$ photoperiod (photosynthetic photon flux density, 104 PPFD: $400 \mathrm{~mol} \mathrm{~m}^{-2} \mathrm{~s}^{-1}$ ) and lasts 3 months from February 2016 to April 2016. Mean 105 temperature and relative humidity were, respectively, $30 \pm 5{ }^{\circ} \mathrm{C}, 55 \pm 5 \%$ day and $16 \pm 2{ }^{\circ} \mathrm{C}$, $10690 \pm 5 \%$ night. After harvest, seed were air-dried and stored at $4{ }^{\circ} \mathrm{C}$ until use for further 107 analysis.

Oil extraction

109 Aniseeds were finely ground in an electric grinder (IKA-WERK. Type: A: 10). $10 \mathrm{~g}$ of each 110 ground sample were extracted using a soxhlet-apparatus with $100 \mathrm{~mL}$ hexane (Analytical 111 Reagent, LabScan, Ltd., Dublin, Ireland) for 6 h. The extraction was protected against light. 112 Oil was removed after mixture filtration and solvent evaporation under reduced pressure.

\section{Total lipid extraction}

114 Total lipids of aniseeds were extracted by the modified method of Bligh and Dyer (1959), 115 according to Marzouk and Cherif(1981).

$116 \quad$ Fatty acid methylation and analysis

117 Total fatty acids were converted into their methyl esters using 3\% sodium methylate in 118 methanol according to the method described by Cecchi et al. (1985).

\section{Essential oil extraction}


120 Aniseed (ripe and dried fruit of Pimpinella anisum L.) were finely ground in an electric 121 grinder (IKA-WERK. Type: A: 10). Triplicate samples of $100 \mathrm{~g}$ were subjected to 122 hydrodistillation in $1 \mathrm{~L}$ of deionized water using a Clevenger apparatus for up to $4 \mathrm{~h}$, time 123 which was necessary for a complete extraction.

\section{Gas Chromatography (GC) analysis}

125 GC analysis of volatile compounds was carried out according to Zaouali et al. (2010) using an 126 Agilent 6980 gas chromatograph equipped with a flame ionisation detector (FID) and an 127 electronic pressure control (EPC) injector attached to HP-INNOWAX polyethylene glycol 128 capillary column $(30 \mathrm{~m} 0.25 \mathrm{~mm})$. The flow of the carrier gas $\left(\mathrm{N}^{2}\right)$ was $1.6 \mathrm{~mL} \mathrm{~min}{ }^{-1}$. The 129 split ratio was 60:1. The analysis was performed using the following temperature program: 130 oven temps isotherm at $35{ }^{\circ} \mathrm{C}$ for $10 \mathrm{~min}$, from 35 to $205{ }^{\circ} \mathrm{C}$ at the rate of $3{ }^{\circ} \mathrm{C} \min ^{-1}$ and 131 isotherm at $205{ }^{\circ} \mathrm{C}$ during $10 \mathrm{~min}$. Injector and detector temperature were held, respectively, 132 at 250 and $300{ }^{\circ} \mathrm{C}$. One micro-liter of the sample (dissolved in hexane as $1 / 50 \mathrm{v} / \mathrm{v}$ ) was 133 injected into the system. Individual peaks were identified by comparison of their retention 134 indices relative to (C6-C22) n-alkanes with those of literature and/or with those authentic 135 compounds available in our laboratory. Percentage compositions of samples were calculated 136 according to the area of the chromatographic peaks using the total ion current.

\section{Gas Chromatography-Mass Spectrometry (GC-MS)}

138 The identification of the EOs was performed using a Hewlett Packard HP5890 series II GC139 MS equipped with a HP5MS column $(30 \mathrm{~m} 0.25 \mathrm{~mm})$. The carrier gas was helium at $1.2 \mathrm{~mL}$ $140 \min 1$. Each sample $(1 \mu \mathrm{L})$ was injected in the split mode $(1: 20)$, the program used was 141 isothermal at $70^{\circ} \mathrm{C}$, followed by $50-240^{\circ} \mathrm{C}$ at a rate of $5^{\circ} \mathrm{C} \min 1$, then held at $240^{\circ} \mathrm{C}$ for 10 $142 \mathrm{~min}$. The mass spectrometer was an HP 5972 and the total electronic impact mode at $70 \mathrm{eV}$ 143 was used. The components were identified by comparing their relative retention times and 
144 mass spectra with the data from the library of EOs constituents, Wiley, Mass-Finder and 145 Adams GC-MS libraries.

\section{Polyphenol extraction and analysis}

147 Preparation of extracts

148 The plant extract was prepared as described earlier by Zahin et al. (2010). Briefly, two 149 hundred (200) grams of dry aniseed powder was soaked in $1 \mathrm{~L}$ of hexane $24 \mathrm{~h}$ with 150 intermittent shaking and at the end of extraction the extract was filtered through Whatman 151 filter paper no.1 (Whatman Ltd., England) to make an hexane fraction (HF). The same dried 152 powder of seeds was further taken for fractionation with the same above procedure with 153 dichloromethane to obtain dichloromethane fraction (DF). After extraction, the same material

154 was successively extracted with ethyl acetate ethanol to obtain EAF and EF, respectively. The 155 filtered fractions were concentrated to dryness under reduced pressure on rotary evaporato at $15640^{\circ} \mathrm{C}$ and stored at $4{ }^{\circ} \mathrm{C}$ for future use.

157 Total phenolic amounts

158 The total phenolic amount of the extracts was determined by using Folin-Ciocalteu reagent 159 (Merck), according to the procedure described by Dewanto et al. (2002).

160 Total flavonoids content

161 Total flavonoid contents (TFC) were measured according to Dewanto et al. (2002).

162 Assessment of Total Condensed Tannins

163 Total tannin contents were measured using the modified vanillin assay described by Sun et al. 164 (2002).

165 DPPH radical scavenging assay 
166 Radical-scavenging activity was determined according to Hanato et al. (1988).

167 Chelating effect on ferrous ions

168 The ferrous ion chelating activity of aniseed extracts was assessed as described by Zhao et al. 169 (2006).

170 Reducing power

171 The method of Oyaizu (1986) was used to assess the reducing power of different seed 172 extracts.

$173 \quad$ RP-HPLC evaluation of phenolic compounds

174 Diluted samples from $P$. anisum seeds were injected to RP-HPLC. The separation of 175 phenolics was performed with an Agilent 1100 series HPLC system equipped with on-line 176 degasser (G 1322A), quaternary pump (G 1311A), a thermostatic auto sampler (G 1313A), 177 column heater (G 1316A) and diode array detector (G 1315A). Instrument control and data 178 analysis were carried out using Agilent HPLC Chemstation 10.1 edition through Windows 179 2000. The separation was carried out on a reverse phase ODS C18 (4 $\mu \mathrm{m}, 25094.6 \mathrm{~mm}$, 180 Hypersil) column used as stationary phase at ambient temperature. The mobile phase 181 consisted of acetonitrile (solvent A) and water sulphuric acid $(0.2 \%)$ (solvent B). The flow 182 rate was kept at $0.5 \mathrm{~mL} \mathrm{~min}^{-1}$. The gradient program was as follows: $15 \mathrm{~A} / 85 \% \mathrm{~B} 0-12 \mathrm{~min}$, $18340 \%$ A $/ 60 \%$ B $12-14 \min , 60 \%$ A/40\% B $14-18 \min , 80 \%$ A/20\% B $18-20$ min, 90\% A/10\% 184 B 20-24 min, 100\% A 24-28 min. The injection volume was $20 \mu 1$ and peaks were monitored 185 at $280 \mathrm{~nm}$. Peak identification was obtained comparing the retention time and the UV spectra 186 of the P.anisum phenolics chromatogram with those of pure standards which were purchased 187 from Sigma (St. Louis, MO, USA). Analyses were performed in triplicates

\section{$188 \quad$ Statistical analysis}


Data were subjected to statistical analysis using statistical program package STATISTICA.

Percentage of each parameter was the mean of six replicates \pm S.D and the differences between individual means were deemed to be significant at $p<0.05$.

192

193

194

195

196

197

198

199

200

201

202

203

204

205

206

207

208

209

210

211

212

\section{Results and discussion}

\section{Oil yield and fatty acid composition}

Nowadays, research has increased to investigate new plant sources of oil from underexploited seeds. Thus, the oils obtained in this experiment, were extracted from $P$. anisum seeds with $n$-hexane in soxhlet apparatus. The highest value was detected with Tunisian aniseeds (TAS) with $11.60 \%$ compared to that of Egyptian ones (EAS) with $9.82 \%$ (Table 1). These values give P. anisum nutritional and industrial importance. We did not find information about oil accumulation in TAS and EAS, but our results were similar to other authors who reported that Brazilian and Polandian aniseeds contained 5-11 mass \% of lipids rich in fatty acids (Besharati-Seidani et al. 2005; Kozlowska et al. 2016) and that the oil content could be fluctuated with geographic origin. Generally, it has been known that Apiaceae crops contained a noticeable yield of oil ranged from $8 \%$ to $24 \%$ (Reiter et al. 1998). As summarized in Table 1, Ten (10) fatty acids were identified. Results showed that the monounsaturated fatty acid (MUFA) proportion was the predominant $(67.65 \%$ and $56.87 \%$ respectively, for TAS and EAS). Among MUFA, petroselinic acid was the most prevalent in oil seeds and interestingly, the Tunisian variety displayed a significantly higher level of this acid (46.60\%) than the Egyptian one $(38.40 \%)$. This is in agreement with the Kleiman and Spencer (1982) and Denev et al. (2011) findings in American and Bulgarian aniseeds. Furthermore, aniseed oil obtained from the two provenances also contained oleic $(\mathrm{C} 18: 1 \Delta 9)$ acid with the proportion exceeding 18\%. Aniseed oil was also characterized by an important level of linoleic acid (C18:2). These two fatty acids play an important role in cell 
213 components and were used by the personal care products industry due to its beneficial 214 properties for skin (Tlili et al. 2014). Moreover, the amount of saturated fatty acids (SFA) in 215 these oils was considerably low, 6.57 for TAS and 14.50 for EAS and represented mainly by 216 palmitic acid (C16:0). Typical of the Apiaceae plant is that the major fatty acid component in

217 the seed oils is petroselinic acid, instead of oleic acid. However, Kozlowska et al. (2016) 218 demonstrated that the fatty acid profile for Polandian aniseeds, in which petroselinic acid was 219 absent, was different from the fatty acid profile of the aniseed analyzed in our study. Also, 220 Matthäus et al. (2014) reported that linoleic acid (59.3\%) was determined as the major 221 constituent of Turkish aniseeds which is totally different from our findings. Previous reports 222 have suggested that genetic factor as well as environment were a source of variability of fatty 223 acids (Bettaieb et al. 2010). Generally, as indicator of nutritional importance, the fatty acid 224 composition also determines the value of edible oils. Indeed, petroselinic acid is of potential 225 industrial significance. It can be oxidatively cleaved to produce a mixture of lauric acid, a 226 compound useful in the production of detergents, and adipic acid, a C6 dicarboxylic acid that 227 can be used in the synthesis of nylon polymer (Murphy 1999).

228 Essential oil content and composition

229 In the present study, the analysis of essential oil content of anise (Suppemental Figure S1) 230 showed that TAS exhibited slightly higher yield than the Egyptian variety $(2.43$ and 1.72\% 231 respectively). These values were in agreement with previously published results (Tabanca et 232 al. 2005; Tepe et al. 2006; Ullaha and Honermeiera 2013). Therefore, it could be concluded 233 that Tunisian aniseeds meet the demand of the European Pharmacopeia (European 234 Pharmacopoeia, 2000).

235 On the other hand, the chemical composition of the aniseed essential oil was markedly similar 236 according the two provenances (Table 2). Fourteen compounds were determined and 237 representing $99 \%$ and $97 \%$ of the total oil respectively for TAS and EAS. 
238 The compounds of analyzed essential oil are grouped in 4 chemical classes according to their

239 functional groupings. Indeed, phenylpropanoides are represented in high amount (95\%, 240 approximately), followed by sesquiterpene hydrocarbons. On the other hand, oxygenated and 241 terpenic hydrocarbons were the minor class in aniseed essential oil.

242 In current studies, trans-anethole was the dominant constituent which proportion varied from 94.30 to $90.41 \%$, respectively for TAS and EAS. This component has a sweet herbaceous 244 odour, sweet taste and was largely used as a substrate for synthesis of various pharmaceutical 245 substances (Kosalec et al. 2005).

246 Other compounds were characterized the essential oil profiles of aniseeds such as $\gamma$ 247 himachalene (2.32-1.08\%), estragole $(0.20-3.74 \%), \beta$-bisabolene $(0.19-0.85 \%)$, diepi- $\alpha-$ 248 cedrene (0.91-0.08\%), respectively for TAS and EAS (Table 2). Indeed, even the same main compounds were present in the two varieties; there was a great difference in their percentages and this can be due to environmental and genetic factors (Bettaieb Rebey et al. 2016).

Based on the previous reports carried out on aniseed oils, trans-anethole, $\gamma$-himachalene and estragole are the characteristic compounds for Pimpinella anisum essential oils (Tabanca et al. 2005; Tepe et al. 2006; Ullaha and Honermeiera 2013). Thus, Singh et al. (2008) mentioned that nine chemical constituents were found by gas chromatography and mass spectrometry (GC-MS) analysis from the essential oil of Indian aniseed and that the major constituent was trans-Anethole (90.1\%) and Fenchone (5\%). Besides, the higher amount of trans-Anethole (96.80\%) was reported in essential oil of Serbian aniseeds by Acimovic et al. (2015). Furthermore, Fitsiou et al. (2016) determined that the main components of the anise essential oil were trans-Anethole $(88.1 \%)$ followed by $\gamma$-himachalene $(4.15 \%)$, and cis-isogenol (4.15\%). While, Al- Maofari et al. (2013) demonstrated that 4-allylanisole was the major compound of Pimpinella anisum L. essential oil. Fortunately, cis-anethole, which is toxic, was not detected in our essential oil, while it was detected in anise essential oil from other origins 
263 (Ullah and Honermeier 2013; Acimovic et al. 2015; Fitsiou et al. 2016). On the other hand, 264 the yield of aniseed may noticeably vary depending on ecological conditions such as 265 temperature, precipitation and soil fertility (Ullah and Honermeier 2013) (Supplemental Table 266 S1).

\section{Total phenolic, flavonoid and tannin contents}

268 It was evident that aniseeds contained noticeable amounts of phenolic content ranged from 26931.22 to 1.82 for TAS and 17.43 to 1.03 for EAS (Supplemental Figure S2). Total phenolic 270 contents extracted from TAS were significantly higher compared to EAS. In both accessions,

271 the highest total phenolic content was obtained with ethyl acetate, followed by ethanol, 272 dichloromethane and hexane fractions. According to Shobha et al. (2013), the total phenolic 273 content of ethyl acetate extract from Indian aniseeds was higher than other solvent extracts. 274 This result is in agreement with the report of Scholz and Rimpler (1989) who showed ethyl 275 acetate is often used as an extraction solvent with a significant selectivity in the extraction of 276 low-molecular-weight phenolic compounds and high-molecular-weight polyphenols methanol 277 as the most suitable solvent for extraction of phenolic compounds. Contrary to these results, 278 Gülçin et al. (2003) reported that the ethanol extract of Turkish aniseeds had highest amount 279 of total phenolic compounds (77.5 mg GAE/g DW) compared to the water extract (30 $\mathrm{mg}$ $280 \mathrm{GAE} / \mathrm{g}$ DW). Bagdassarian et al. (2013) reported that total phenolic content evaluated in 281 Bulgarian aniseed methanolic extract was $46.17 \mathrm{mg} / \mathrm{g}$ DW. These changes could be ascribed 282 to the variations in pedoclimatic conditions. Additionally, the ethyl acetate extract of aniseeds 283 obtained from Tunisian provenance showed higher polyphenol content than the Egyptian one, 284 suggesting that phenolic biosynthesis in $P$. anisum is greatly influenced by genetic factors as 285 mentioned by Bettaieb et al. (2012) in the case of Cuminum cyminum seeds.

286 Total flavonoid content of aniseeds varied from 2.76 to $48.52 \mathrm{mg} \mathrm{CE} / \mathrm{g}$ DW for TAS and from 2871.88 to $31.08 \mathrm{mg} \mathrm{CE} / \mathrm{g}$ DW for EAS. There were significant differences in total flavonoid 
concentration among the two accessions. Total flavonoid contents extracted from TAS were higher than those from EAS. Regarding flavonoid solubility, the solvent classification with respect to their extraction efficiency was similar to that made for polyphenols having an order of ethyl acetate $>$ ethanol $>$ dichloromethane $>$ hexane. Shobha et al. (2013) also showed that ethyl acetate is an efficient solvent for extracting flavonoids from aniseeds.

As found for phenolics and flavonoids, condensed tannin contents were found to vary depending on the solvent used. Condensed tannin contents were less abundant than flavonoid contents in aniseeds obtained by different solvents The highest condensed tannin contents were recorded when extraction was achieved using ethyl acetate $(5.11 \mathrm{mg}$ EC/g DW) for TAS and ethanol (4.29 mg EC/g DW) for EAS (Supplemental Figure S3). Shobha et al. (2013) reported that n-butanol was more efficient than ethyl acetate to extract condensed tannins for Indian aniseeds.

As matter of fact, it is also important to note that genetic and geographic factors, culture conditions, climatic changes, harvesting time, storage and manipulation procedures, among others, should significantly affect the composition of phenolic and, consequently, the biological potential and their use as healthy promoters.

\section{Antioxidant activity}

Various studies have focused on natural antioxidants in plant extracts and their applications in food systems to prevent oxidation. The most widely used synthetic antioxidants in food (butylated hydroxytoluene BHT, butylated hydroxyanisole BHA) are very effective in their role as antioxidants. However, their use in food products has been failing off due to their instability or their suspected action as promoters of carcinogenesis (Namiki 1990). For this reason, there is a growing interest in the studies of natural healthy (nontoxic) additives as potential antioxidants (Tomaino et al. 2005). 
312 P. anisum extracts exhibited variable abilities to quench DPPH radical as a function of the

313 solvent type (Supplemental Figure S4). Ethanol and dichloromethane extracts of EAS showed

314 the highest abilities to scavenge $\mathrm{DPPH}$ radical with $\mathrm{IC}_{50}=12.58$ and $16.45 \mu \mathrm{g} / \mathrm{mL}$,

315 respectively. This activity was more potent than that of the well known synthetic antioxidant

316 BHT $(\mathrm{IC} 50=24.12 \mu \mathrm{g} / \mathrm{ml})$. In addition, Ethyl acetate extract of TAS had higher potential to

317 scavenge DPPH radical $\left(\mathrm{IC}_{50}=18.75 \mu \mathrm{g} / \mathrm{mL}\right)$ than the positive control BHT. The lowest

318 antiradical capacity was found in hexane extracts of aniseeds with $\mathrm{IC}_{50}=168.25 \mu \mathrm{g} / \mathrm{mL}$ for

319 TAS and $194.32 \mu \mathrm{g} / \mathrm{mL}$ for EAS. Nickavar and Al Sadat Abolhasani (2009) reported that the

320 radical scavenging activities of Iranian aniseeds were mainly intense for ethyl acetate extract,

321 followed by water, chloroform and hexane extract. Gülçin et al. (2003) mentioned that the

322 ethanol and water extracts of Turkish aniseeds had lower antiradical potential than the

323 positive controls (BHT, BHA and $\alpha$-tocopherol). These significant differences in antioxidant

324 potential between solvent systems were essentially due to the difference in polarity, and thus

325 different extractability of the antioxidative compounds (Ksouri et al. 2008).

326 The effect of solvent on the antioxidant abilities of TAS and EAS was also assessed by the

327 estimation of chelating and reducing powers estimation (Table 3). TAS exhibited higher

328 chelating and reducing powers than EAS which may be due to a slightly different phenolic

329 composition between the two accession seed extracts. The different extracts of both aniseed

330 accessions showed power antioxidant activities, but ethyl acetate led to the highest chelating

331 power $\left(\mathrm{IC}_{50}=9.73 \mathrm{mg} / \mathrm{mL}\right.$ for $\mathrm{TAS}$ and $33.65 \mathrm{mg} / \mathrm{mL}$ for $\left.\mathrm{EAS}\right)$ and the lowest reducing

332 capacity $\left(\mathrm{EC}_{50}=510.22 \mathrm{mg} / \mathrm{mL}\right.$ for TAS and $687 \mathrm{mg} / \mathrm{mL}$ for EAS). It was also observed that

333 despite the inability of the $P$. anisum seed extracts to compete with the positive controls

334 (ascorbic acid in iron reducing and EDTA in iron chelating), these extracts did possess mild

335 antioxidant activities and may be considered as potential preservatives for food utilization

336 where aniseeds were preferred due to its safety. Gülçin et al. (2003) also reported that the 
337 ethanol and water extracts of Turkish aniseeds had lower chelating and reducing powers than

338 the positive controls (BHT, BHA and $\alpha$-tocopherol).

339 Moreover, from the results of present study, it is evident that the antioxidant activities of 340 P.anisum, are related to various phenolic compounds present in one or more fractions. In 341 general, the higher polyphenols extraction yield corresponds with the higher antioxidant 342 activity, probably due to the combined action of the substances present in variable 343 concentrations and their high hydrogen atom donating abilities. Similarly, a linear correlation 344 between DPPH radical scavenging activity and polyphenolic extract has been reported as 345 variable ranges in different food plants (Siddhuraju and Becker 2003)

346 Identification of phenolic compounds using HPLC

347 Generally, phenolic compounds act as important contributors to the antioxidant potential of 348 plant extracts. So, their characterization could provide considerable benefits to individuals, 349 mainly through inciting their use as healthy promoters.

350 In this context, ethyl acetate and ethanol were the most efficient solvents to extract phenolics 351 for TAS and EAS accessions. Despite these two accessions contained identical phenolic 352 compounds, qualitative and quantitative differences were found between the two solvent 353 extracts (Table 4). For the two accessions, Ethyl acetate and ethanol extracts contained more 354 flavonoids (55.57\% and $72.70 \%$ for TAS and $55.81 \%$ and $73.29 \%$ for EAS, respectively) than 355 phenolic acids (45.97\% and $25.26 \%$ for TAS and $41.56 \%$ and $24.43 \%$ for EAS, respectively). 356 A total of 15 phenolic compounds were identified. The phenolic compositions of TAS and 357 EAS revealed that ethyl acetate extracts showed higher proportions of naringin $(32.12 \%$ for 358 TAS and $33.33 \%$ for EAS), chlorogenic acid $(29.37 \%$ for TAS and $24.18 \%$ for EAS) and 359 rosmarinic acid (10.90\% for TAS and 10.32 for EAS). However, ethanol extracts were richer 360 in larcitrin $(25.26 \%$ for TAS and $26.87 \%$ for EAS), rosmarinic acid $(18.54 \%$ for TAS and 361 $20.59 \%$ for EAS) and cirsimartin (13.97\% for TAS and $17.62 \%$ for EAS). 
362 Variations in phenolic composition between the two solvent extracts could be explained by

363 the difference in polarity, and thus different extractability, of the antioxidative compounds

364 (Djeridane et al. 2006; Maisuthisakul et al. 2007). Several studies showed that solvent polarity

365 leads to significantly different extraction capacities for phenolic compounds in plants (Parida

366 et al. 2004; Galvez et al. 2005). Quantitative analysis of total phenolic compounds using

367 HPLC indicated that ethyl acetate extract contained more total phenolics $(10.18 \mathrm{mg} / \mathrm{g}$ for TAS

368 and $7.68 \mathrm{mg} / \mathrm{g}$ for EAS) than ethanol extract $(7.44 \mathrm{mg} / \mathrm{g}$ for TAS and $5.73 \mathrm{mg} / \mathrm{g}$ for EAS).

369 However, phenolic contents obtained by HPLC were significantly lower than those obtained

370 by the spectrophotometrical method. This was predictable due to the low selectivity of Folin-

371 Ciocalteu reagent, as it reacts positively with different phenolic and non-phenolic substances

372 (Que et al. 2006). Martins et al. (2016) quantified the total phenolic comnpounds of P. anisum

373 seeds by HPLC having $42.09 \mathrm{mg} / \mathrm{g}$ and they qualified phenolic composition counting six

374 hydroxycinnamic acid derivatives and ten flavones derivatives mainly luteolin and apigenin

375 derivatives. In earlier study of Kunzemann and Herrmann (1977), isolation and structure

376 elucidation of flavonoid constituents from anise spice by means of chromatography on

377 cellulose columns lead to isolation of quercetin 3-glucuronide, rutin, luteolin 7-glucoside,

378 isoorientin, isovitexin apigenin 7-glucoside and luteolin glycoside. Shobha et al. (2013)

379 reported the abundance of apigenin and luteolin in ethyl acetate fraction of aniseeds.

380 However, Zielinski et al. (2014) reported the richness of anise tea extract in chlorogenic acid

381 and quercetin as found in ethyl acetate aniseed extract of our work.

382 The results presented here constitute the first information on the phytochemical composition

383 and antioxidant activities of aniseed fractions of Tunisian and Egyptian accessions. Aniseed

384 antioxidant activity was high enough for the plant to be a new and natural source of

385 antioxidant substances for its use as natural additives in food. To understand their mechanism

386 of action as bioactive components, further fractionation of ethyl acetate and ethanol extracts, 
387 isolation of phenolic compounds and determination of their biological activities in vitro and in

388 vivo are needed.

\section{Acknowledgements}

390 The authors thank Pr. Abderazzak Smaoui for identification of the plant.

391 Supplemental data

392 Supplemental data (Table S1, Figure S1, Figure S2, Figure S3, Figure S4, and Figure S5) can 393 be accessed at supplementary materials section.

\section{References}

395 Acimovic M, Tesevic V, Todosijevic M, Djisalov J, Oljaca S. 2015. Compositional 396 characteristics of the essential oil of Pimpinella anisum and Foeniculum vulgare grown 397 in Serbia. Bot Serb 39: 9-14.

398 Al Maofari S, El Hajjaji A, Debbab S, Zaydoun B, Ouaki R, Charof Z, et al. 2013. Chemical 399 composition and antibacterial properties of essential oils of Pimpinella anisum L. 400 growing in Morocco and Yemen. Sci Study Res 14: 11-16.

401 Albuquerque TG, Santos F, Sanches-Silva A, Beatriz Oliveira M, Bento C, Costa HS. 2016. 402 Nutritional and phytochemical composition of Annona cherimola Mill. fruits and by403 products: Potential health benefits. Food Chem 193: 187-195.

Bagdassarian VLC, Bagdassarian KS, Atanassova MS. 2013. Phenolic profile, antioxidant 405 and antimicrobial activities from the Apiaceae family (dry seeds). Mintage J Pharm Med $406 \quad$ Sci 2: 26-31.

407 Besharati-seidani A, Jabbari A, Amini Y. 2005. Headspace solvent micro extraction: a very 408 rapid method for identification of volatile component of Iranian Pimpinella anisum seed. $409 \quad$ Anal Chim Acta 530: 155 - 161. 
410 Bettaieb Rebey I, Bourgou S, Ben Slimen Debez I, Jabri Karoui I, Hamrouni Sellami I, 411 Msaada K, et al. 2012. Effects of extraction solvents and provenances on phenolic 412 contents and antioxidant activities of cumin (Cuminum cyminum L.) seeds. Food $413 \quad$ Bioprocess Technol 5: 2827-2836.

414 Bettaieb Rebey I, Bourgou S, Rahali FZ, Msaada K, Ksouri R, Marzouk B. 2016. Relation 415 between salt tolerance and biochemical changes in cumin (Cuminum cyminum L.) $416 \quad$ seeds. J Food Drug Anal 25:391-402.

417 Bligh EG, Dyer WJ. 1959. A rapid method for total lipid extraction and purification. Can J $418 \quad$ Biochem Physiol 37: 911-917.

419 Cecchi G, Biasini S, Castano J. 1985. Methanolyse rapide des huiles en solvants. Note de 420 laboratoire. Rev Franc Corps Gras 4: 163-164.

421 Denev RV, Kuzmanova IS, Momchilova SM, Nikolova-Damyanova BM. 2011. Resolution 422 and Quantification of Isomeric Fatty Acids by Silver Ion HPLC: Fatty Acid Composition 423 of Aniseed Oil (Pimpinella Anisum, Apiaceae). J AOAC Int 94: 4-8.

424 Dewanto V, Wu X, Adom KK, Liu RH. 2002. Thermal processing enhances the nutritional 425 value of tomatoes by increasing total antioxidant activity. J Agric Food Chem 50: 30104263014.

427 Djeridane MB, Yousfi D, Nadjemi P, Boutassouna N. 2006. Antioxidant activity of some 428 Algerian medicinal plants extracts containing phenolic compounds. Food Chem 97: 654$429 \quad 660$.

430 Ebrahimabadi AH, Ebrahimabadi EH, Bidgoli ZD, Kashi FJ, Mazoochi A, Batooli H. 2010. 431 Composition and antioxidant and antimicrobial activity of the essential oil and extracts of 432 Stachys inflata Benth from Iran. Food Chem 119: 452-458.

433 European Pharmacopoeia, 2000. Dritter Nachtrag, 3rd ed. Council of Europe, Strasbourg, pp. $434 \quad 499-500$. 
Fitsiou E, Mitropoulou G, Spyridopoulou K, Tiptiri-Kourpeti A, Vamvakias M, Bardouki H, et al. 2016. Phytochemical Profile and Evaluation of the Biological Activities of Essential Oils Derived from the Greek Aromatic Plant Species Ocimum basilicum, Mentha spicata, Pimpinella anisum and Fortunella margarita. Molecules 21: 1069.

Galvez CJ, Martin-Cordero PA, Houghton M. 2005. Antioxidant Activity of methanol extracts obtained from Plantago species. J Agric Food Chem 53: 1927-1933.

Gülçin İ, Oktay M, Kireçci E, Küfrevioğlu Öİ. 2003. Screening of antioxidant and antimicrobial activities of anise (Pimpinella anisum L.) seed extracts. Food Chem 83: 371-382.

Hatano T, Kagawa H, Yasuhara T, Okuda T. 1988. Two new flavonoids and other constituents in licore root: their relative astringency and radical scavenging affects. Chem Pharm Bull 36: 1090-2097.

Kleiman R, Spenser GF. 1982. Search for new industrial oils. XVI. Umbelliflorae seed oils rich in petroselinic acid. J Amer Oil Chern Soc 59: 29-38.

Kosalec S, Pepeljnjak M, Jandrlić M. 2005. Influence of media and temperature on gliotoxin production in Aspergillus fumigates strains. Arh Hig Rada Toksikol 56: 269-273.

Kozłowska M, Gruczyńska E, Ścibisz I, Rudzińska M. 2016. Fatty acids and sterols composition, and antioxidant activity of oils extracted from plant seeds. Food Chem 213: 450-6.

Ksouri R, Megdiche W, Falleh H, Trabelsi N, Boulaaba M, Smaoui A, et al. 2008. Influence of biological, environmental and technical factors on phenolic content and antioxidant activities of Tunisian halophytes. Comp Rend Biol 331: 865-73.

Kunzemann J, Herrmann K. 1977. Isolation and identification of flavon(ol)-O-glycosides in caraway (Carum carvi L.), fennel (Foeniculum vulgare Mill.), anise (Pimpinella anisum 
459 L.), and coriander (Coriandrum sativum L.), and of flavon-C-glycosides in anise-I. 460 Phenolics of spices. Z Lebensm Unters For 164: 194-200.

461 Li A, Li S, Zhang, Y., Xu X, Chen Y, Li H. 2014. Resources and biological activities of 462 natural polyphenols. Nutr 6: 6020-6047.

463 Maisuthisakul P, Suttajit M, Pongsawatmanit R. 2007. Assessment of phenolic content and 464 free radical-scavenging capacity of some Thai indigenous plants. Food Chem 4: 1409$465 \quad 1418$.

466 Marques V, Farah A. 2009 Chlorogenic acids and related compounds in medicinal plants and 467 infusions. Food Chem 113: 1370-1376.

468 Martins N, Barrosa L, Buelgac CS, Ferreiraa ICFR. 2016. Antioxidant potential of two 469 Apiaceae plant extracts: A comparative study focused on the phenolic composition. Ind $470 \quad$ Crops Prod 79: 188-194.

471 Marzouk B, Cherif A. 1981. Formation des lipides dans l'olive : I-Formation des lipides $472 \quad$ neutres. Oléag 36: 77-81.

473 Matthäus B, Özcan MM, Al Juhaimi F. 2014 Variations in oil, fatty acid and tocopherol $474 \quad$ contents of some Labiateae and Umbelliferae seed oils. Qual Assur Saf Crop 7: 103$475 \quad 107$.

476 Murphy DJ. 1999. Production of novel oils in plants. Curr Opin Biotechnol 10: 175-180.

477 Namiki M. 1990. Antioxidants/antimutagens in food. Crit Rev Food Sci Nutr 29: 273-300.

478 Nickavar B, Al Sadat Abolhasani F. 2009. Screening of antioxidant properties of seven 479 Umbelliferae fruits from Iran. Pak J Pharm Sci 22: 30-35.

480 Oyaizu M. 1986. Studies on products of browning reactions: antioxidative activities of 481 products of browning reaction prepared from glucosamine. Jap J Nutr 44: 307-315.

482 Ozel A. 2009. Anise (Pimpinella anisum): changes in yields and component composition on 483 harvesting at different stages of plant maturity. Exp Agric 45: 117-126. 
484 Parida AK, Das AB, Sanada Y, Mohanty P. 2004. Effects of salinity on biochemical 485 components of the mangrove, Aeceras corniculatum. Aquatic Bot 80:77-87.

486

Que F, Mao L, Pan X. 2006. Antioxidant activities of five Chinese rice wines and the 487

488

489

490

491

492

493

494

495

496

497

498

499

500

501

502

503

504

505

506 
507 Tabanca N, Douglas AW, Bedir E, Dayan FE, Kirimer N, Baser KHC, et al. 2005. Patterns of

508 essential oil relationships in Pimpinella (Umbelliferae) based on phylogenetic relationships

509 using nuclear and chloroplast sequences. Plant Genet Resour 3: 149-163.

510 Tepe B, Sokmen M, Akpulat HA, Sokmen A. 2006. Screening of the antioxidant potentials of 511 six Salvia species from Turkey. Food Chem 95: 200-204.

512 Terao J, Piskula MK. 1997. Flavonoids as inhibitors of lipid peroxidation in membranes. In C.

513 A. Rice-Evans, \& L. Packer (Eds.), Flavonoids in health and disease (pp. 277-295).

$514 \quad$ New York: Marcel Dekker.

515 Tlili N, Mejri H, Yahia Y, Saadaoui E, Rejeb S, Khaldi A, et al. 2014. Phytochemicals and 516 antioxidant activities of Rhus tripartitum (Ucria) fruits depending on locality and 517 different stages of maturity. Food Chem 160: 98-103.

518 Tomaino A, Cimino F, Zimbalatti V, Venuti V, Sulfaro, V, De Pasqual A. 2005. Influence of 519 heating on antioxidant activity and the chemical composition of some spice essential oils. $520 \quad$ Food Chem 89: 549-554.

521 Ullah H, Honermeier B. 2013. Fruit yield, essential oil concentration and composition of three 522 anise cultivars (Pimpinella anisum L.) in relation to sowing date, sowing rate and 523 locations. Ind Crop Prod 42: 489-499.

524 WHO-World Health Organization. 2000. Pautas generales paralas metodologías de 525 investigación y evaluación de la medicina tradicional, Geneva, Switzerland.

526 Zahin M, Aqil F, Ahmad I. 2010. Broad spectrum antimutagenic activity of antioxidant active 527 fraction of Punica granatum L. peel extracts. Mutat Res 703: 99-107.

528 Zaouali Y, Bouzaine T, Boussaid M. 2010. Essential oils composition in two Rosmarinus 529 officinalis L. varieties and incidence for antimicrobial and antioxidant activities. Food $530 \quad$ Chem Toxicol 48: 3144-3152. 
531 Zhao G, Xiang Z, Ye T, Yuan Y, Guo Z. 2006. Antioxidant activities of Salvia miltiorrhiza $532 \quad$ and Panax notoginseng. Food Chem 99: 767-774.

533 Zielinski AAF, Haminiuk CWI, Alberti A, Nogueira A, Demiate IM, Granato DA. 2014. 534 Comparative study of the phenolic compounds and the in vitro antioxidant activity of 535 different Brazilian teas using multivariate statistical techniques. Food Res Inter 60: 246536254.

537

538

539

540

541

542

543

544

545

546

547

548

549

550

551

552

553

554

555 
Table 1 Oil yield and fatty acid composition (\%) of Tunisian and Egyptian anise (Pimpinella anisum) seeds (Means of six replicates \pm S.D). Values with different superscripts $(\mathrm{a}-\mathrm{b})$ are significantly different at $p<0.05$.

\begin{tabular}{lcc}
\cline { 2 - 3 } & TAS & EAS \\
\hline Oil yield (\%) & $11.60 \pm 0.03^{\mathrm{a}}$ & $9.82 \pm 0.02^{\mathrm{b}}$ \\
\hline Saturated fatty acid (SFA) (\%) & $0,16 \pm 0.03^{\mathrm{a}}$ & $0,11 \pm 0.01^{\mathrm{a}}$ \\
Capric acid (C10:0) & $0,52 \pm 0.01^{\mathrm{a}}$ & $0,44 \pm 0.02^{\mathrm{a}}$ \\
Lauric acid (C12:0) & $0,07 \pm 0.01^{\mathrm{a}}$ & $0,02 \pm 0.00^{\mathrm{a}}$ \\
Myristic acid (C14:0) & $4,90 \pm 0.22^{\mathrm{b}}$ & $13,20 \pm 0.09^{\mathrm{a}}$ \\
Palmitic acid (C16:0) & $0,85 \pm 0.04^{\mathrm{a}}$ & $0,66 \pm 0.01^{\mathrm{a}}$ \\
Stearic acid (C18:0) & $0,07 \pm 0.01^{\mathrm{a}}$ & $0,07 \pm 0.00^{\mathrm{a}}$ \\
Arachidic acid (C20:0) & 6.57 & 14.5 \\
Total & & \\
Unsaturated fatty acid (UFA) (\%) & $46,60 \pm 0.22^{\mathrm{a}}$ & $38,40 \pm 0.11^{\mathrm{b}}$ \\
Petroselinic acid (C18:1 $\Delta 6)$ & $21,05 \pm 0.08^{\mathrm{a}}$ & $18,47 \pm 0.13^{\mathrm{b}}$ \\
Oleic acid (C18:1 $\Delta 9)$ & $22,99 \pm 0.44^{\mathrm{a}}$ & $23,18 \pm 0.22^{\mathrm{a}}$ \\
Linoleic acid (C18:2) & $1,07 \pm 0.01^{\mathrm{a}}$ & $0,58 \pm 0.04^{\mathrm{b}}$ \\
Linolénic acid (C18:3) & 91.71 & 80.63 \\
Total & & \\
\hline Val & & \\
\hline
\end{tabular}

Values with different superscripts (a-b) are significantly different at $p<0.05$ (means of six replicates); SFA: saturated fatty acid; UFA: unsaturated fatty acid. 
Table 2 Essential oil composition of Tunisian and Egyptian anise (Pimpinella anisum) seeds (Means of six replicates \pm S.D). Values with different superscripts $(\mathrm{a}-\mathrm{b})$ are significantly different at $p<0.05$.

\begin{tabular}{lcccc}
\hline \multicolumn{1}{c}{ Compounds* } & $\mathbf{R I}^{\mathrm{a}}$ & $\mathbf{R I}^{\mathrm{b}}$ & \multicolumn{2}{c}{$\%$} \\
\cline { 4 - 5 } & & & $\mathbf{T A S}$ & $\mathbf{E A S}$ \\
\hline Terpene hydrocarbons & & & 0.13 & 0.04 \\
Linalool & 1097 & 1557 & $0.13 \pm 0.01^{\mathrm{a}}$ & $0.04 \pm 0.04^{\mathrm{b}}$ \\
Oxygenated Monoterpene & & & 0.06 & 0.02 \\
$\alpha$-Terpinene & 1018 & 1249 & $0.06 \pm 0.01^{\mathrm{a}}$ & $0.02 \pm 0.00^{\mathrm{a}}$ \\
Phenylpropanoids & & & 95.78 & 94.99 \\
Anisole & 918 & 1720 & $0.97 \pm 0.05^{\mathrm{a}}$ & $0.52 \pm 0.03^{\mathrm{b}}$ \\
Estragole & 1197 & 1430 & $0.20 \pm 0.03^{\mathrm{b}}$ & $3.74 \pm 0.13^{\mathrm{a}}$ \\
trans-Anethole & 1253 & 1740 & $94.30 \pm 0.01^{\mathrm{a}}$ & $90.41 \pm 0.22^{\mathrm{b}}$ \\
-Anisaldehyde & 1250 & 1718 & $0.17 \pm 0.01^{\mathrm{a}}$ & $0.10 \pm 0.07^{\mathrm{a}}$ \\
Cis-Isoeugenol & 1359 & 2180 & $0.14 \pm 0.01^{\mathrm{a}}$ & $0.22 \pm 0.02^{\mathrm{a}}$ \\
Sesquiterpene hydrocarbons & & & 3.95 & 2.48 \\
$\beta$-Elemene & 1388 & 1465 & $0.07 \pm 0.66^{\mathrm{a}}$ & $0.09 \pm 2.11^{\mathrm{a}}$ \\
$\gamma$-Himachalene & 1484 & 1690 & $2.32 \pm 0.04^{\mathrm{a}}$ & $1.08 \pm 0.01^{\mathrm{b}}$ \\
Zingiberene & 1494 & 1672 & $0.30 \pm 0.03^{\mathrm{a}}$ & $0.25 \pm 0.03^{\mathrm{a}}$ \\
$\beta$-Himachalene & 1505 & 1942 & $0.12 \pm 0.02^{\mathrm{a}}$ & $0.11 \pm 0.01^{\mathrm{a}}$ \\
$\beta$-Bisabolene & 1506 & 1832 & $0.19 \pm 0.02^{\mathrm{b}}$ & $0.85 \pm 0.01^{\mathrm{a}}$ \\
Isolongifolene & 1532 & 2003 & $0.04 \pm 0.00^{\mathrm{a}}$ & $0.02 \pm 0.00^{\mathrm{a}}$ \\
Diepi- $\alpha$-cedrene & 1575 & 2020 & $0.91 \pm 0.02^{\mathrm{a}}$ & $0.08 \pm 0.00^{\mathrm{b}}$ \\
Total identified & & & 99.74 & 97.53 \\
\hline
\end{tabular}

Volatile compounds percentages in the same line with different letters $(\mathrm{a}-\mathrm{b})$ are significantly different at $\mathrm{P}<$ 0.05 (means of six replicates). $\mathrm{RI}^{\mathrm{a}}$ Order of elution in apolar column (HP-5); $\mathrm{RI}^{\mathrm{b}}$ Order of elution in polar column (HP Innowax), MS: mass spectrum. 
Table 3. Antioxidant activities of TAS and EAS extracts

\begin{tabular}{|c|c|c|c|c|}
\hline & \multicolumn{2}{|c|}{$\begin{array}{c}\text { Chelating ability } \\
\left(\mathrm{IC}_{50} \cdot \mathrm{mg} / \mathrm{mL}\right)\end{array}$} & \multicolumn{2}{|c|}{$\begin{array}{c}\text { Reducing power } \\
\left(\mathrm{EC}_{50} \cdot \mu \mathrm{g} / \mathrm{mL}\right)\end{array}$} \\
\hline & TAS & EAS & TAS & EAS \\
\hline Ethanol & $19.05 \pm 0.38^{\mathrm{Ab}}$ & $55.46 \pm 0.25^{\mathrm{Bb}}$ & $273.45 \pm 0.55^{\mathrm{Ba}}$ & $454.63 \pm 0.54^{\mathrm{Aa}}$ \\
\hline Ethyl acetate & $9.73 \pm 0.87^{\mathrm{Aa}}$ & $33.65 \pm 0.83^{\mathrm{Ba}}$ & $510.22 \pm 1.94^{\mathrm{Ac}}$ & $687 \pm 1.77 \mathrm{~A}^{\mathrm{Bc}}$ \\
\hline EDTA & \multicolumn{2}{|c|}{$0.03 \pm 0.01$} & \multicolumn{2}{|c|}{-} \\
\hline Ascorbic acid & \multicolumn{2}{|c|}{-} & \multicolumn{2}{|c|}{$42 \pm 0.84$} \\
\hline
\end{tabular}

Each value in the table was obtained by calculating the average of three experiments; The data marked with the different capital letter for the provenance and small letter for the solvents. in the table of each $\mathrm{IC}_{50}$ or $\mathrm{EC}_{50}$ value share significant differences at $\mathrm{P}<0.05$ (Duncan test). 
Table 4. Phenolic compounds of ethyl acetate and ethanol extracts from Tunisian and Egyptian aniseeds

\begin{tabular}{|c|c|c|c|c|c|c|c|c|}
\hline & \multicolumn{4}{|c|}{ Ethyl acetate } & \multicolumn{4}{|c|}{ Ethanol } \\
\hline & \multicolumn{2}{|c|}{ TAS } & \multicolumn{2}{|c|}{ EAS } & \multicolumn{2}{|c|}{ TAS } & \multicolumn{2}{|c|}{ EAS } \\
\hline & $\mathrm{mg} / \mathrm{mL}$ & $\%$ & $\mathrm{mg} / \mathrm{mL}$ & $\%$ & $\mathbf{m g} / \mathbf{m L}$ & $\%$ & $\mathbf{m g} / \mathbf{m L}$ & $\%$ \\
\hline Phenolic acid & $4.68^{\mathrm{a}}$ & $45.97^{\mathrm{a}}$ & $3.18^{b}$ & $41.56^{b}$ & $1.88^{\mathrm{c}}$ & $25.26^{\mathrm{c}}$ & $1.40^{d}$ & $24.43^{c}$ \\
\hline Gallic acid & $0.01 \pm 0.00^{\mathrm{a}}$ & $0.09 \pm 0.01^{\mathrm{B}}$ & $0.02 \pm 0.01^{\mathrm{a}}$ & $0.26 \pm 0.01^{\mathrm{B}}$ & $0.01 \pm 0.01^{\mathrm{a}}$ & $0.13 \pm 0.02^{\mathrm{B}}$ & $0.07 \pm 0.01^{\mathrm{a}}$ & $1.22 \pm 0.02^{\mathrm{A}}$ \\
\hline Chlorogenic acid & $2.99 \pm 0.01^{\mathrm{a}}$ & $29.37 \pm 0.22^{\mathrm{A}}$ & $1.85 \pm 0.01^{b}$ & $24.18 \pm 0.02^{B}$ & - & - & & \\
\hline Caffeic acid & - & - & - & - & $0.20 \pm 0.02$ & $2.68 \pm 0.03$ & $0.05 \pm 0.01^{\mathrm{a}}$ & $1.22 \pm 0.02^{\mathrm{a}}$ \\
\hline Syringic acid & $0.03 \pm 0.01^{b}$ & $0.29 \pm 0.08^{B}$ & $0.10 \pm 0.01^{\mathrm{a}}$ & $1.30 \pm 0.01^{\mathrm{A}}$ & - & - & & \\
\hline$p$-Coumaric acid & $0.53 \pm 0.00^{\mathrm{a}}$ & $5.20 \pm 0.01^{\mathrm{A}}$ & $0.28 \pm 0.01^{b}$ & $3.66 \pm 0.07^{\mathrm{B}}$ & $0.21 \pm 0.03^{b}$ & $2.82 \pm 0.05^{\mathrm{C}}$ & $0.04 \pm 0.01^{\mathrm{c}}$ & $0.69 \pm 0.01^{\mathrm{D}}$ \\
\hline Rosmarinic acid & $1.11 \pm 0.01^{\mathrm{b}}$ & $10.90 \pm 0.01^{\mathrm{C}}$ & $0.79 \pm 0.01^{c}$ & $10.32 \pm 0.05^{\mathrm{C}}$ & $1.38 \pm 0.04^{\mathrm{a}}$ & $18.54 \pm 0.02^{\mathrm{B}}$ & $1.18 \pm 0.03^{\mathrm{a}}$ & $20.59 \pm 0.07^{\mathrm{A}}$ \\
\hline Ellargic acid & $0.02 \pm 0.01^{\mathrm{c}}$ & $0.19 \pm 0.01^{b}$ & $0.14 \pm 0.01^{\mathrm{a}}$ & $1.83 \pm 0.01^{\mathrm{a}}$ & $0.08 \pm 0.01^{\mathrm{ab}}$ & $1.07 \pm 0.04^{b}$ & $0.06 \pm 0.01^{b}$ & $1.04 \pm 0.01^{\mathrm{a}}$ \\
\hline Flavonoids & $5.25^{\mathrm{a}}$ & $51.57^{\mathrm{C}}$ & $4.27^{b}$ & $55.81^{\mathrm{C}}$ & $5.41^{\mathrm{a}}$ & $72.70^{A}$ & $4.20^{b}$ & $73.29^{B}$ \\
\hline Epicatechin-3-Ө-gallate & $0.14 \pm 0.01^{\mathrm{c}}$ & $1.37 \pm 0.02^{\mathrm{C}}$ & $0.07 \pm 0.01^{\mathrm{c}}$ & $0.91 \pm 0.01^{\mathrm{CD}}$ & $0.64 \pm 0.03^{\mathrm{a}}$ & $8.60 \pm 0.04^{\mathrm{A}}$ & $0.39 \pm 0.03^{b}$ & $6.80 \pm 0.09^{\mathrm{B}}$ \\
\hline Coumarin & $0.64 \pm 0.01^{\mathrm{a}}$ & $6.28 \pm 0.01^{\mathrm{A}}$ & $0.56 \pm 0.01^{b}$ & $7.32 \pm 0.03^{\mathrm{A}}$ & $7>$ & - & & \\
\hline Rutin & $0.12 \pm 0.02^{\mathrm{c}}$ & $1.17 \pm 0.05^{\mathrm{D}}$ & $0.19 \pm 0.01^{c}$ & $2.48 \pm 0.04^{C}$ & $0.82 \pm 0.01^{\mathrm{a}}$ & $11.02 \pm 0.06^{\mathrm{A}}$ & $0.55 \pm 0.01^{b}$ & $9.59 \pm 0.05^{\mathrm{B}}$ \\
\hline Quercetin & $0.51 \pm 0.03^{\mathrm{c}}$ & $5.00 \pm 0.02^{\mathrm{B}}$ & $0.41 \pm 0.01^{\mathrm{c}}$ & $5.35 \pm 0.06^{\mathrm{B}}$ & $0.99 \pm 0.02^{\mathrm{a}}$ & $13.30 \pm 0.01^{\mathrm{A}}$ & $0.69 \pm 0.02^{b}$ & $12.04 \pm 0.02^{\mathrm{A}}$ \\
\hline Naringin & $3.27 \pm 0.03^{\mathrm{a}}$ & $32.12 \pm 0.01^{\mathrm{A}}$ & $2.55 \pm 0.01^{\mathrm{ab}}$ & $33.33 \pm 0.01^{\mathrm{A}}$ & $0.04 \pm 0.00^{b}$ & $0.53 \pm 0.01^{\mathrm{B}}$ & $0.02 \pm 0.00^{b}$ & $0.34 \pm 0.02^{\mathrm{B}}$ \\
\hline Apigenin & $0.57 \pm 0.00^{\mathrm{a}}$ & $5.59 \pm 0.01^{\mathrm{AB}}$ & $0.49 \pm 0.01^{\mathrm{a}}$ & $6.40 \pm 0.02^{\mathrm{A}}$ & - & $\bar{P}$ & - & \\
\hline Larcitrin & - & - & & & $1.88 \pm 0.07^{\mathrm{a}}$ & $25.26 \pm 0.08^{\mathrm{A}}$ & $1.54 \pm 0.03^{\mathrm{a}}$ & $26.87 \pm 0.05^{\mathrm{A}}$ \\
\hline Cirsimartin & - & - & & & $1.04 \pm 0.05^{\mathrm{a}}$ & $13.97 \pm 0.04^{\mathrm{B}}$ & $1.01 \pm 0.02^{\mathrm{a}}$ & $17.62 \pm 0.04^{\mathrm{A}}$ \\
\hline NI & $0.25 \pm 0.01^{\mathrm{a}}$ & $2.45 \pm 0.03^{b}$ & $0.27 \pm 0.01^{\mathrm{a}}$ & $3.52 \pm 0.03^{\mathrm{a}}$ & $0.15 \pm 0.02^{\mathrm{a}}$ & $2.01 \pm 0.02^{\mathrm{A}}$ & $0.13 \pm 0.01^{\mathrm{a}}$ & $2.26 \pm 0.02^{\mathrm{B}}$ \\
\hline Total & 10.18 & 100 & 7.65 & 100 & 7.44 & 100 & 5.73 & 100 \\
\hline
\end{tabular}

Values are means of six replications ( $N= \pm 6 \mathrm{SD}$ ). The data marked with capital letters (A-D) and small letters (a-d) in the same line indicate significant differences at $\mathrm{P}<0.05$ (Duncan test). 


\section{Comparative assessment of phytochemical profiles and antioxidant} properties of Tunisian and Egyptian anise (Pimpinella anisum L.) seeds

I. BETTAIEB REBEY ${ }^{* 1,2}$, S. BOURGOU ${ }^{1}$, W. AIDI WANNES ${ }^{1}$, I. HAMROUNI SELAMI ${ }^{1}$, M. SAIDANI TOUNSII ${ }^{1}$, B. MARZOUK ${ }^{1}$, M. LAURE FAUCONNIER ${ }^{2}, \&$ R.KSOURI ${ }^{1}$

\section{Supplementary materials}




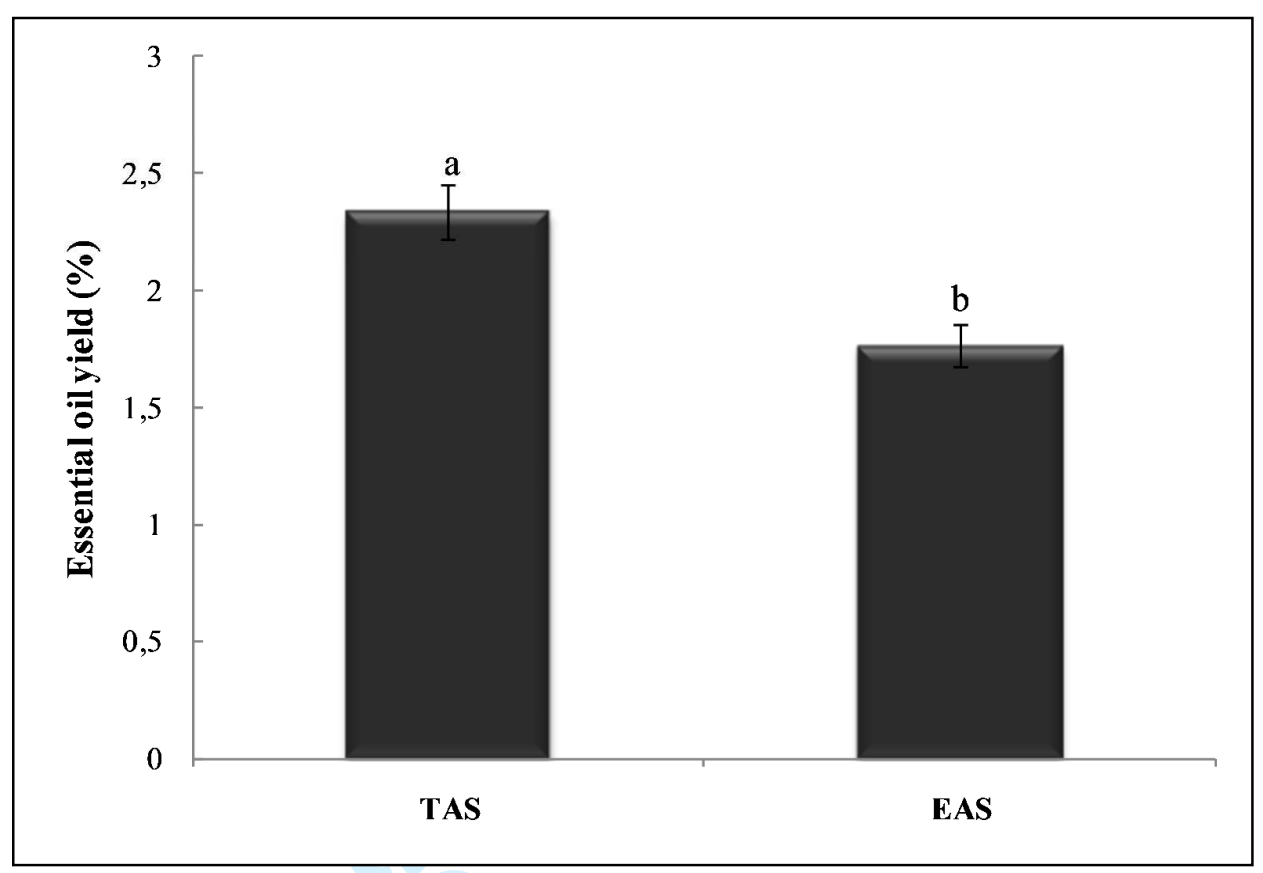

Figure S1. Essential oil yields of Tunisian and Egyptian anise (Pimpinella anisum) seeds (Means of six replicates \pm S.D). Values with different superscripts $(a-b)$ are significantly different at $p<0.05$. 
Table S1. Comparative table between the main volatile compounds (\%) detected in Pimpinella anisum seeds cultivated in different countries.

\begin{tabular}{|c|c|c|c|c|c|c|c|c|c|c|c|}
\hline 10 & India & & ia & & ceco & Yemen & Pakistan & Egypte & Greek & Turkey & Sudan \\
\hline $\begin{array}{l}11 \text { Volatile } \\
1 \text { fompounds (\%) } \\
13\end{array}$ & $\begin{array}{l}\text { Singh et } \\
\text { al. (2008) }\end{array}$ & $\begin{array}{l}\text { Samojlik et } \\
\text { al. (2012) }\end{array}$ & $\begin{array}{l}\text { Acimovic et } \\
\text { al. (2015) }\end{array}$ & $\begin{array}{l}\text { Ghouati et } \\
\text { al. (2012) }\end{array}$ & $\begin{array}{l}\text { Al Moafri } \\
\text { et al (2013) }\end{array}$ & $\begin{array}{l}\text { Al Moafri } \\
\text { et al (2013) }\end{array}$ & $\begin{array}{c}\text { Ullah and } \\
\text { Honermeir, (2013) }\end{array}$ & $\begin{array}{c}\text { AbdRaheem \& } \\
\text { Oraby (2015) }\end{array}$ & $\begin{array}{l}\text { Fitsiou et } \\
\text { al. (2016) }\end{array}$ & $\begin{array}{l}\text { Tepe et al. } \\
\text { (2016) }\end{array}$ & $\begin{array}{c}\text { Hassan and } \\
\text { Elhassan (2017) }\end{array}$ \\
\hline 1t4ans-Anethole & 90.1 & 88.49 & 96.8 & 81.19 & 7.40 & 3.54 & 84.07 & 82.1 & 88.1 & 82.8 & 78.21 \\
\hline $1 \not \zeta s$-Anethole & - & - & - & - & - & - & 0.18 & 5.8 & 0.43 & - & - \\
\hline 16 Himachalene & - & 3.13 & 1.84 & 6.22 & - & - & 5.75 & - & 4.15 & 0.2 & - \\
\hline cijs-isogenol & - & 1.99 & - & - & . & - & - & 1.3 & - & - & - \\
\hline Toinalool & - & 1.79 & - & - & - & - & - & 2.3 & - & - & - \\
\hline 1.8stragole & 2.3 & - & - & 0.46 & - & - & - & 2.5 & - & 14.5 & 1.86 \\
\hline 19 -Terpineole & - & - & - & - & - & - & - & 1.5 & - & - & - \\
\hline 20 enchone & 5 & - & - & - & 6.16 & 4.12 & - & -- & - & - & - \\
\hline 21 ongifolene & - & - & - & - & - & - & - & - & - & - & 2.64 \\
\hline 2Z̈ngiberene & - & - & 0.11 & - & - & - & 0.59 & - & - & - & 1.06 \\
\hline 23amphene & - & - & - & - & - & - & - & - & - & - & - \\
\hline 24imonene & - & - & - & - & - & - & - & - & - & - & - \\
\hline 2૬allylanisole & - & & - & - & - & - & - & - & - & - & - \\
\hline 2øimonene & - & - & - & - & 9.75 & 5.53 & - & - & - & - & - \\
\hline 2łallylanisole & - & - & - & - & 76.70 & 85.28 & - & - & - & - & - \\
\hline
\end{tabular}

28 27fallylanisole $\quad-$ : low proportion $(<0.1 \%)$ or not detected.




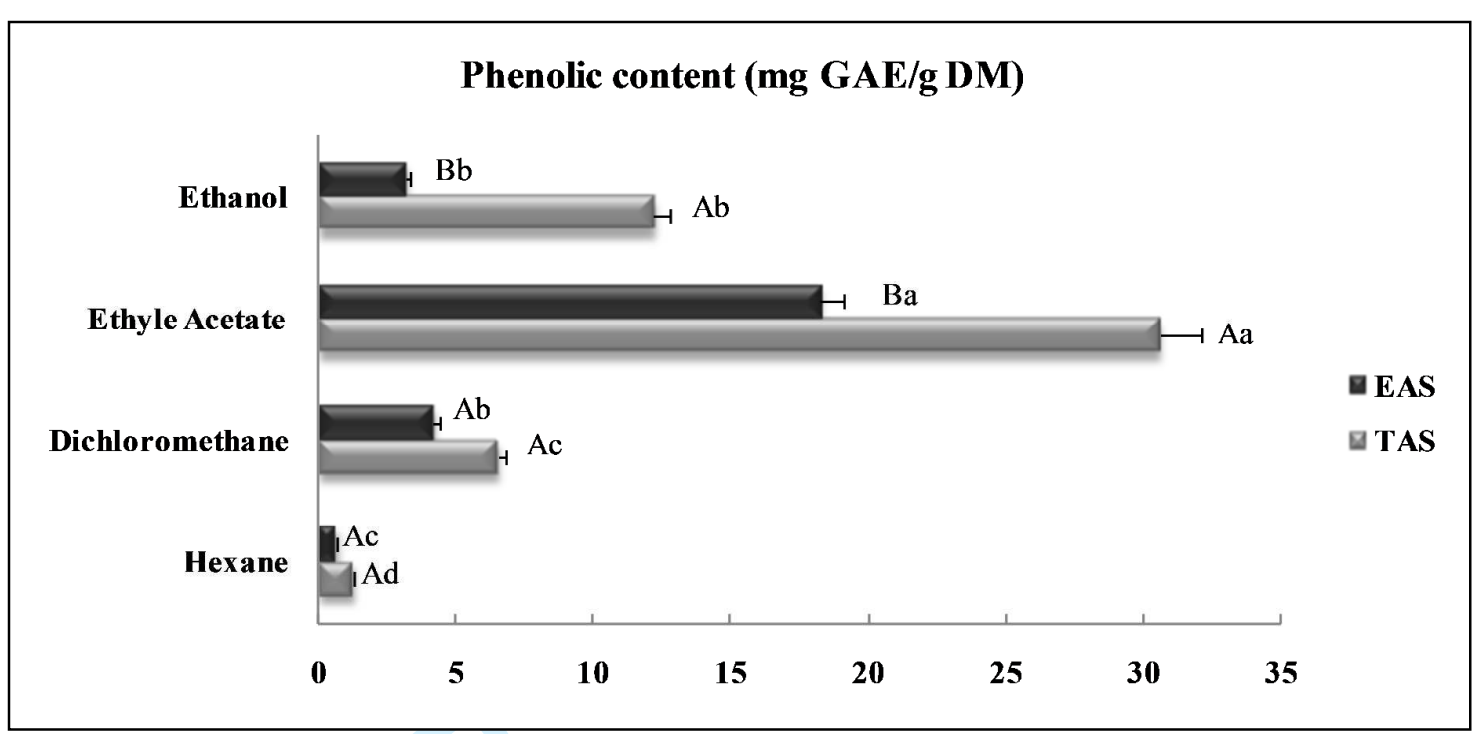

Figure S2. Total phenolic contents (mg GAE/g DM) of anise (Pimpinella anisum) seed extracts. The data marked with the different capital letter for provenance and small letter for the solvents in the table value share significant differences at $P<0.05$ (Duncan test). Values are means of six replications $(\mathrm{N}=6 \pm \mathrm{S} . \mathrm{D})$; $\mathrm{CE}$ : catechin equivalents; TAS: Tunisian anise seeds; EAS: Egyptian anise seeds. 


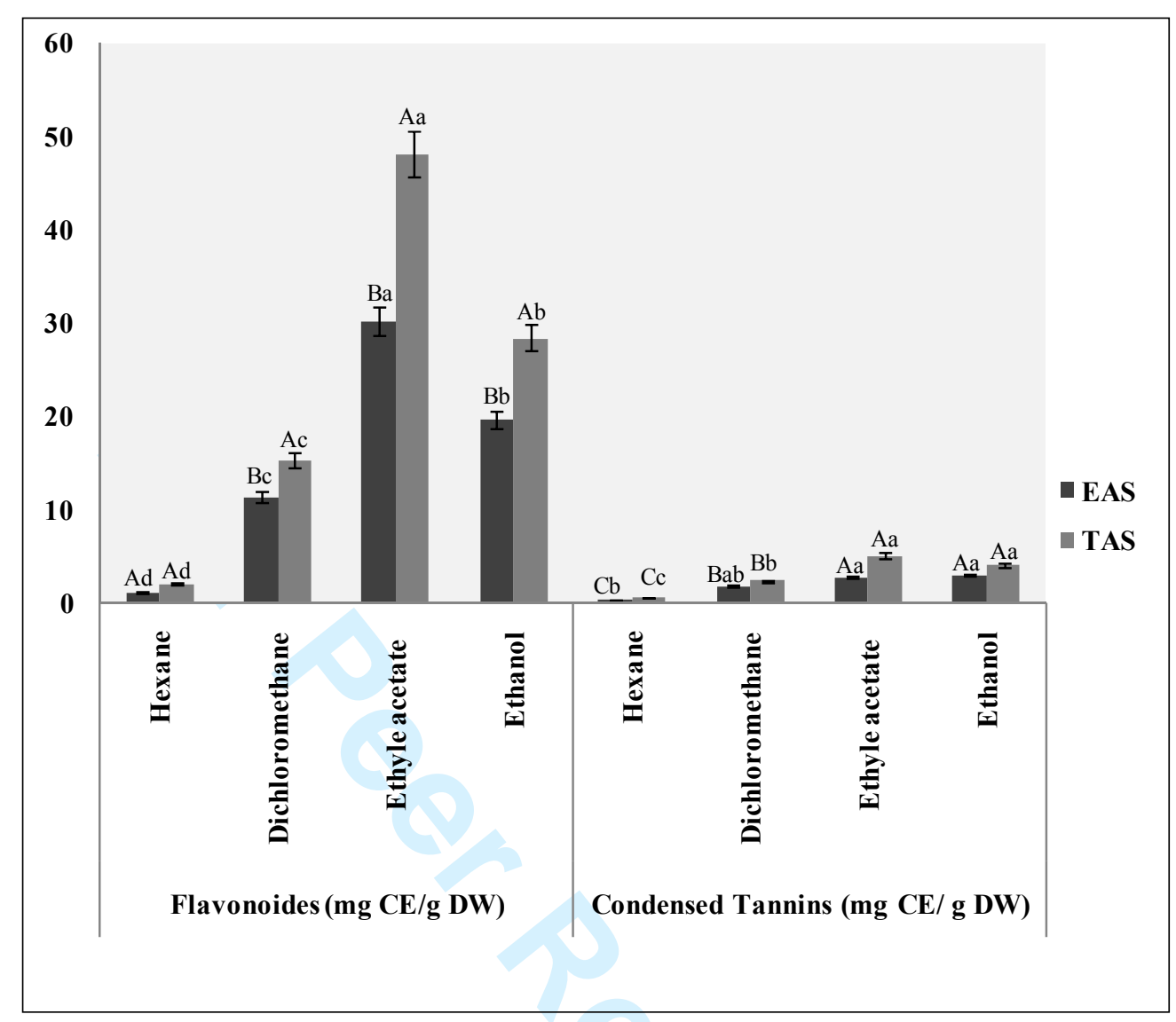

Figure S3. Total Flavonoid and tannin contents (mg CE/g DM) of anise (Pimpinella anisum) seed extracts. The data marked with the different capital letter for provenance and small letter for the solvents, in the table value share significant differences at $P<0.05$ (Duncan test). Values are means of six replications $(\mathrm{N}=6 \pm \mathrm{S} . \mathrm{D})$; $\mathrm{CE}$ : catechin equivalents; TAS: Tunisian anise seeds; EAS: Egyptian anise seeds. 


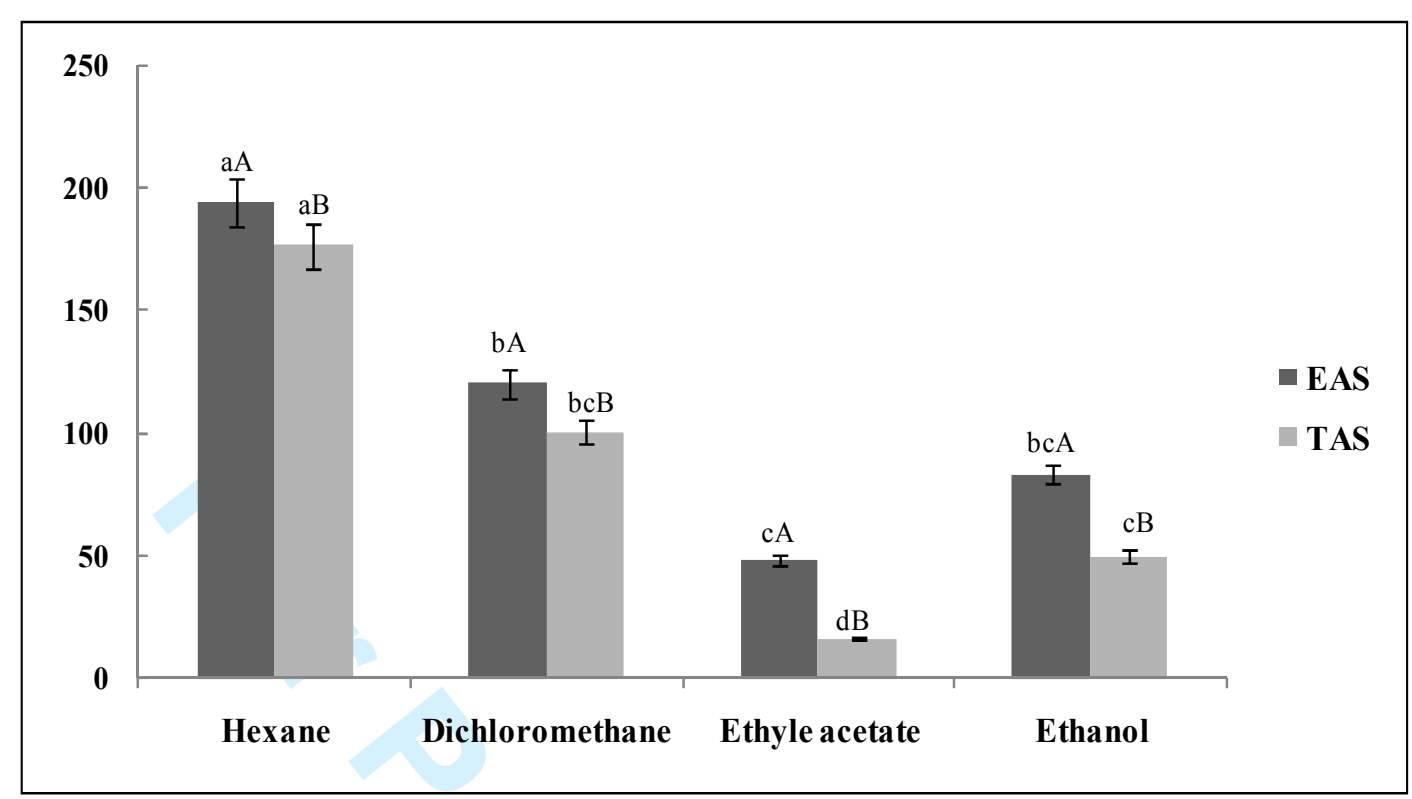

Figure S4. DPPH scavenging activity (IC50) of different seed extracts (TAS and EAS). Values are means of six replications $(\mathrm{N}=6 \pm \mathrm{SD})$. The data marked with the different capital letter for the provenance and small letter for the solvent. In the histograms of each IC50 value share significant differences at $\mathrm{P}<0.05$ (Duncan test). 


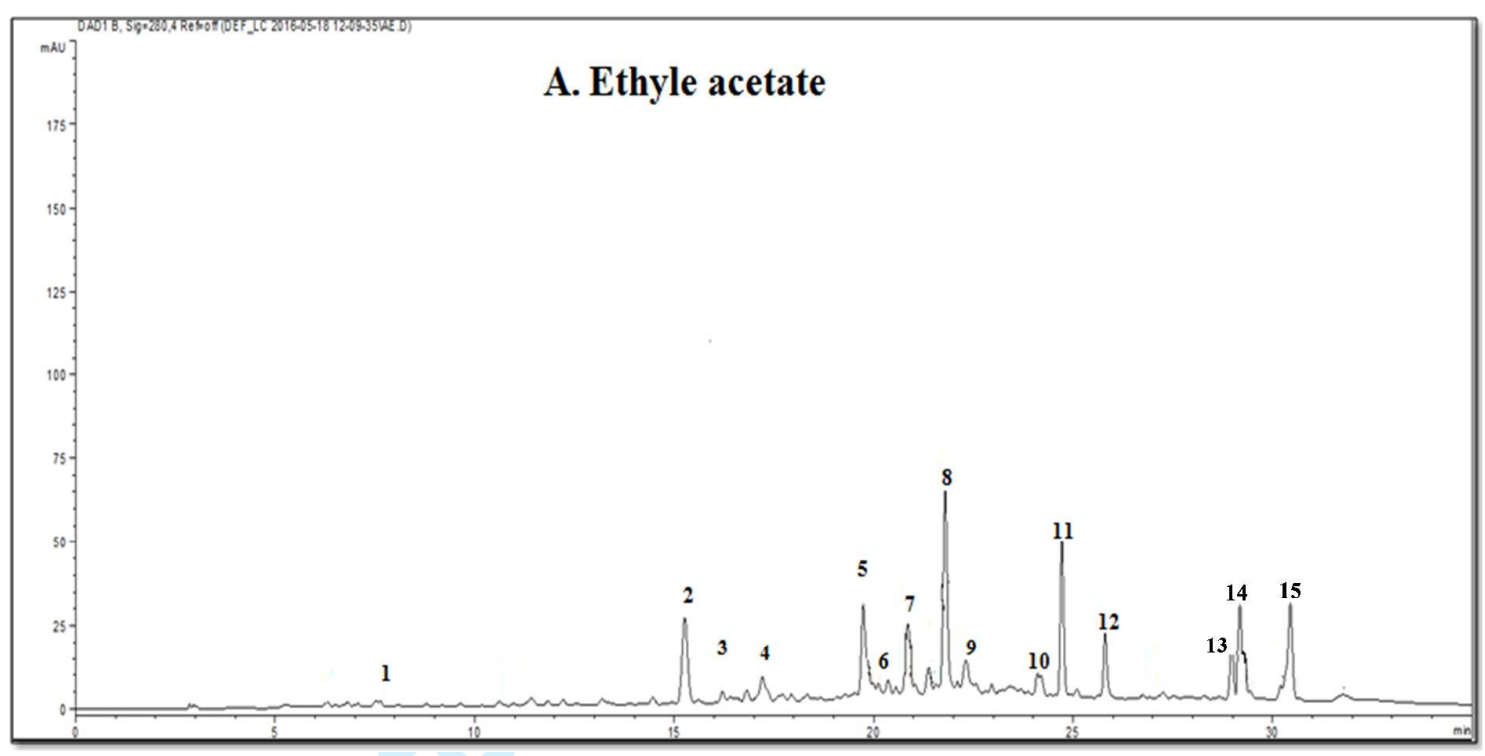

1. Gallic acid; 2. Chlorogenic acid; 3. Epicatechin $3 \Theta$ gallate; 4.Syringic acid; 5. $p$-coumaric acid; 6. Coumarine; 7. Rutin ; 8. Rosmarinic acid; 9. Ellargic acid; 10. Quercetin; 11. Naringin; 12. Apigenin; 13. NI; 14: NI; 15: NI.

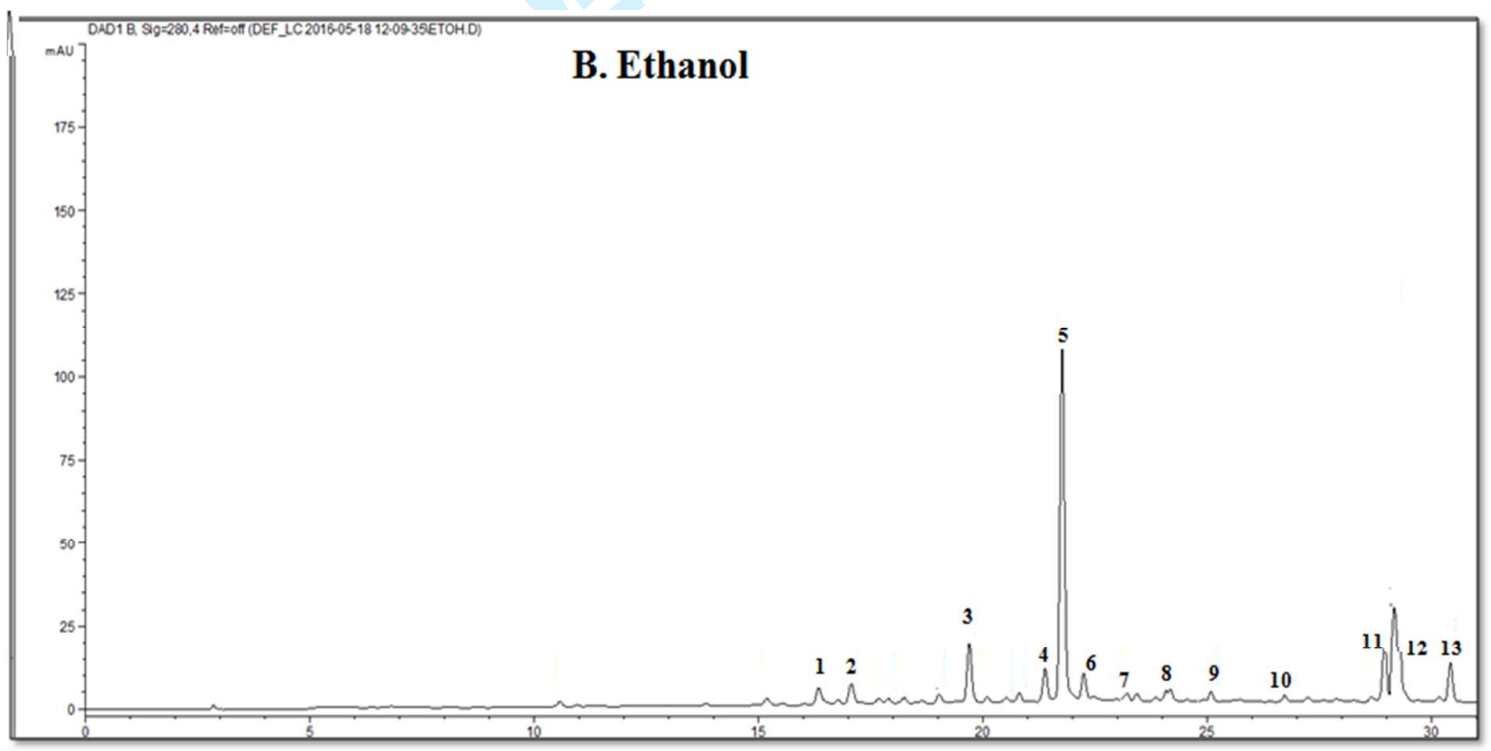

1. Epicatechin-3Ө gallate; 2. Caffeic acid; 3. p-coumaric acid; 4. Rutin; 5. Rosmarinic acid; 6. Ellargic acid; 7. Quercetin; 8. Naringin; 9. Larcitrin; 10. Cirsimartin; 11. NI; 12. NI; 13. NI.

Figure S5. Reverse-phase high -performance liquid chromatography (RP-HPLC) chromatographic profiles of the phenolic compound in ethyl acetate (A) and ethanol (B) extracts of anise (Pimpinella anisum) seeds monitored at $280 \mathrm{~nm}$, NI; not identified. 